\title{
L-Tryptophan, a Study on Interactions in Cu(II) Binary and Ternary Complexes in Aqueous Solution
}

\author{
S. A. A. Sajadi
}

Sharif University of Technology, Institute of Water \& Energy, Tehran, P. O. Box 11155-8639, Iran

\begin{abstract}
The acidity and stability constants of $\mathrm{M}(\mathrm{Trp})^{\mathrm{i}} \mathrm{M}: \mathrm{Cu}^{2+}, \mathrm{Cu}\left(\mathrm{Bpy}^{\mathrm{ii}}\right)^{2+}$, and $\mathrm{Cu}\left(\mathrm{Phen}^{\mathrm{iii}}\right)^{2+}$ complexes, were determined by potentiometric $\mathrm{pH}$ titration. It is shown that the stability of the binary $\mathrm{Cu}(\mathrm{Trp})$ complexes is determined by the basicity of the carboxylate group on one side and amino group on the other side. It is demonstrated that the equilibrium, $\mathrm{Cu}\left(\mathrm{Har}^{\mathrm{iv}}\right)^{2+}+\mathrm{Cu}(\mathrm{Trp}) \rightleftharpoons \mathrm{Cu}(\mathrm{Har})(\operatorname{Trp})+\mathrm{Cu}^{2+}$, is displacement due to the well known experience that mixed ligand complexes formed by a divalent $3 \mathrm{~d}$ ion, a heteroaromatic $\mathrm{N}$ base and an $\mathrm{O}$ donor ligand possess increased stability. The other part of this displacement, which amount on average to an increased stability of the mixed ligand $\mathrm{Cu}(\mathrm{Bpy})(\mathrm{Trp})$ and $\mathrm{Cu}(\mathrm{Phen})(\mathrm{Trp})$ complexes of about 0.97 or $1.31 \mathrm{log}$ unit. The stability constants of the $1: 1$ complexes formed between $\mathrm{Cu}^{2+}$, $\mathrm{Cu}(\mathrm{Bpy})^{2+}$ or $\mathrm{Cu}(\mathrm{Phen})^{2+}$ and $\mathrm{Trp}^{2-}$, were determined by potentiometric $\mathrm{pH}$ titration in aqueous solution $\left(I=0.1 \mathrm{M}, \mathrm{NaNO}_{3}\right.$, $\left.25^{\circ} \mathrm{C}\right)$. The order of the stability constants was reported.
\end{abstract}

Keywords Tryptophan, Divalent Metal Ions, Potentiometric Titration, Acidity and Stability Constants

\section{Introduction}

L-Trp or D-Trp; sold for medical use as Tryptan (fig. 1)[1] is one of the 20 standard amino acids, as well as an essential amino acid in the human diet. It is encoded in the standard genetic code as the codon $U G G$. Tryptophan (Trp) is considered exceptional in its diversity of biological functions[2]. It is a vital constituent of proteins and indispensable in human nutrition for establishing and maintaining a positive nitrogen balance[3]. Besides, some of its derivatives are potent drugs[4]. Trp is widely used in food industry. It is sometimes added to dietary and feed products as a food fortifier in order to maintain the amino acid balance of the food and correct possible dietary deficiencies. Trp can also be used to study structure and dynamics of the proteins because of its indole moiety[5]. In particular, Trp is the precursor of the neurotransmitter serotonin and plays an important role in brain function and related regulatory mechanisms[6]. In addition, Trp is an important and frequently used starting material in the chemical synthesis of a range of pharmaceuticals[7].

The distinguishing structural characteristic of tryptophan is that it contains an indole functional group. It is an essential amino acid as demonstrated by its growth effects on rats. Now it is interesting to investigate the complex bilding of ternary systems with Trp. We would like to determine the

* Corresponding author:

sajadi@sharif.ac.ir (S. A. A. Sajadi)

Published online at http://journal.sapub.org/chemistry

Copyright (C) 2011 Scientific \& Academic Publishing. All Rights Reserved thermodynamic constants of ternary complexes such as $\mathrm{Cu}(\mathrm{Har})(\operatorname{Trp})$.

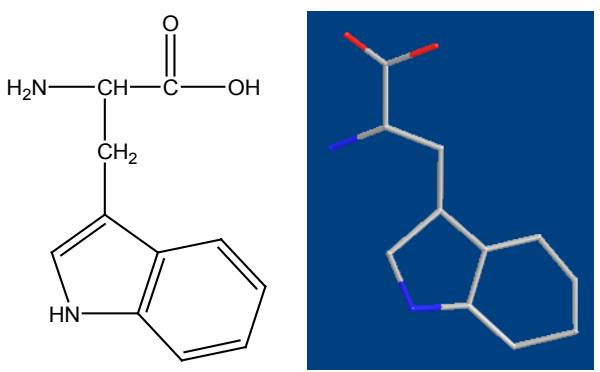

Figure 1. Chemical formula of L-Tryptophan

\section{Experimental}

\subsection{Materials}

Chemicals were purchased from Merck. Copper(II) nitrate trihydrated, sodium nitrate, potassium hydrogen phthalate and standard solutions of sodium hydroxide (titrasol), 2,2'bipyridyl, 1,10-phenanthroline, nitric acid, EDTA and of the buffer solutions of $\mathrm{pH} 4.0,7.0$ and 9.0 were from Merck. All the starting materials were pro analysis and used without further purification. Water was purified by Mili-Q water purification system, deionized and distillated.

\section{2. pH titrations}

Reagents: Carbonate-free sodium hydroxide $0.03 \mathrm{M}$ was preparated and standardized against sodium hydrogen phthalate and a standard solution of nitric acid $0.5 \mathrm{mM}$. Copper (II) nitrate solution $(0.03 \mathrm{M})$ was prepared by dis- 
solving the above substance in water and was standardized with standard solution of EDTA $0.1 \mathrm{M}$ (triplex).

\subsection{Apparatus}

All pH titrations was performed using a Metrohm 794 basic automatic titrator (Titrino), coupled with a Hero thermostating bath at $25^{\circ} \mathrm{C}\left( \pm 0.1^{\circ} \mathrm{C}\right)$ and a Metrohm combined glass electrode $(\mathrm{Ag} / \mathrm{AgCl})$. The $\mathrm{pH}$ meter was calibrated with Merck standard buffer solutions (4.0, 7.0 and 9.0).

\subsection{Procedure}

For the determination of acid dissociation constants of the ligand $\operatorname{Trp}$ an aqueous solution $(0.3 \mathrm{mM})$ of the protonated ligand was titrated with $0.03 \mathrm{M} \mathrm{NaOH}$ at $25^{\circ} \mathrm{C}$ under nitrogen atmosphere and ionic strength of $0.1 \mathrm{M}, \mathrm{NaNO}_{3}$. For the determination of binary (one ligand and $\mathrm{Cu}^{2+}$ ) and ternary systems $\left(\mathrm{Cu}^{2+}\right.$, one of the other L ligand (Har) and Trp), the ratios used were $1: 1,1: 2 \mathrm{Cu}(\mathrm{II})$ : ligand and $1: 1: 1, \mathrm{Cu}(\mathrm{II})$ : Trp : Har, $0.3 \mathrm{mM}$. This solution was titrated with $0.03 \mathrm{M}$ $\mathrm{NaOH}$ under the same conditions mentioned above. Each titration was repeated seven times in order to check the reproducibility of the data.

\section{Calculation}

The acid dissociation constants, $K_{H_{2}(T r p)}^{H}$ and $K_{H(T / p)}^{H}$ for $\mathrm{H}_{2}(\operatorname{Trp})$ were calculated by an algebraic method. The equilibria involved in the formation of 1:1 complex of Trp and a divalent metal ion may be expressed as equations (3) \& (4).

\section{Results and Discussion}

In this section we would discuss the resulted data.

\subsection{Acidity Constants}

Tryptophan (Trp) can accept one proton on carboxylic group, for which the following deprotonation equilibria hold:

$$
\begin{gathered}
\mathrm{H}_{2}(\operatorname{Trp}) \rightleftharpoons \mathrm{H}^{+}+\mathrm{H}(\operatorname{Trp})^{-} \\
K_{H_{2}(T r p)}^{H}=\left[\mathrm{H}(\operatorname{Trp})^{-}\right]\left[\mathrm{H}^{+}\right] /\left[\mathrm{H}_{2}(\operatorname{Trp})\right]
\end{gathered}
$$

Trp can release one other proton from amine group according following deprotonation equilibria:

$$
\begin{gathered}
\mathrm{H}(\operatorname{Trp})^{-} \rightleftharpoons \mathrm{H}^{+}+\operatorname{Trp}^{2-} \\
K_{H(T r p)}^{H}=\left[\operatorname{Trp}^{2-}\right]\left[\mathrm{H}^{+}\right] /\left[\mathrm{H}(\operatorname{Trp})^{-}\right]
\end{gathered}
$$

Also the two protons in $\mathrm{H}_{2}$ (Trp) are certainly bound at the terminal acetate group and amine group, i.e., it is released from $-\mathrm{CO}_{2} \mathrm{H}$ or $-\mathrm{NH}_{2}$ according to equilibrium (1) \& (2). These values are, as accepted, close to the pKa values of $-\mathrm{CO}_{2} \mathrm{H}$ which is $2.22[8]$.

\subsection{Stability of Binary and Ternary Complexes}

If we abbreviate for simplicity $\mathrm{Cu}^{2+}, \mathrm{Cu}(\mathrm{Bpy})^{2+}$, and $\mathrm{Cu}(\mathrm{Phen})^{2+}$ with $\mathrm{M}^{2+}$, one may write the following two equilibria (3) \& (4):

$$
\begin{aligned}
& \mathrm{M}^{2+}+\mathrm{H}(\operatorname{Trp})^{-} \rightleftharpoons \mathrm{M}(\mathrm{H} ; \operatorname{Tr} \mathrm{p})^{+} \\
& K_{M(H ; T r p)}^{M}=\left[\mathrm{M}(\mathrm{H} ; \operatorname{Trp})^{+}\right] /\left[\mathrm{M}^{2+}\right]\left[\mathrm{H}(\operatorname{Trp})^{-}\right]
\end{aligned}
$$

$$
\begin{gathered}
\mathrm{M}^{2+}+(\operatorname{Trp})^{2-} \rightleftharpoons \mathrm{M}(\operatorname{Trp}) \\
K_{M(\operatorname{Trp})}^{M}=[\mathrm{M}(\operatorname{Trp})] /\left[\mathrm{M}^{2+}\right]\left[\operatorname{Trp}^{2-}\right]
\end{gathered}
$$

The experimental data of the potentiometric $\mathrm{pH}$ titrations may be completely by considering the above mentioned equilibria (1) through (4), if the evaluation is not carried into the $\mathrm{pH}$ range where hyrdoxo complex formation occurs.

The stability of ternary complexes may be evaluated by the following equilibrium:

$$
\mathrm{mA}+\mathrm{nB}+\mathrm{qM}+\mathrm{rH} \rightleftharpoons \mathrm{A}_{\mathrm{m}} \mathrm{B}_{\mathrm{n}} \mathrm{M}_{\mathrm{q}} \mathrm{H}_{\mathrm{r}}
$$

where $\mathrm{M}$ is the metal ion, $\mathrm{H}$ is the proton, $\mathrm{A}$ and $\mathrm{B}$ are the ligand. The global stability constant for the ternary complexes may be represented as following:

$$
\log \beta_{\mathrm{pqrs}}=\left[\mathrm{A}_{\mathrm{m}} \mathrm{B}_{\mathrm{n}} \mathrm{M}_{\mathrm{q}} \mathrm{H}_{\mathrm{r}}\right] /[\mathrm{A}]^{\mathrm{m}}[\mathrm{B}]^{\mathrm{n}}[\mathrm{M}]^{\mathrm{q}}[\mathrm{H}]^{\mathrm{r}}
$$

It is possible to define the stability constants for ternary complexes in relation to their binary ones [9], represented by the equilibrium (6) \& (7).

$$
\begin{gathered}
\mathrm{M}+\mathrm{L}_{1} \rightleftharpoons \mathrm{ML}_{1} \\
K_{M\left(L_{1}\right)}^{M}=\left[\mathrm{ML}_{1}\right] /\left[\mathrm{M}^{2+}\right]\left[\mathrm{L}_{1}\right] \\
\mathrm{ML}_{1}+\mathrm{L}_{2} \rightleftharpoons \mathrm{ML}_{1} \mathrm{~L}_{2} \\
K_{M\left(L_{1} L_{2}\right)}^{M}=\left[\mathrm{ML}_{1} \mathrm{~L}_{2}\right] /\left[\mathrm{ML}_{1}\right]\left[\mathrm{L}_{2}\right]
\end{gathered}
$$

Differences between the stability constants of the ternary and binary complexes show the tendency of the formation of ternary species[10]. This could be expected by Eq. (8):

$$
\begin{aligned}
\Delta \log \mathrm{K} & =\log K_{M\left(L_{1} L_{2}\right)}^{M L_{1}}-\log K_{M\left(L_{2}\right)}^{M} \\
& =\log K_{M\left(L_{1} L_{2}\right)}^{M L_{2}}-\log K_{M\left(L_{1}\right)}^{M}
\end{aligned}
$$

The difference between the constant refined from experimental data and those calculated statistically using Eq. (8) indicates the possibility of ligand-ligand interaction.

\subsection{Potentiometric Analyses}

The model of species for this ternary system that was used in superquad program includes all the species of table 1 as well as the hydrolysis of $\mathrm{Cu}^{2+}[11,12]$. The stability constants of the binary complexes were refined separately using the titration data of this system in a 1:1 and 1:2 ligand: $\mathrm{Cu}^{2+}$ ratio in the same conditions of temperature and ionic strength. They were fixed and, consequently, only ternary species were refined in ternary model of the species. The results are summarized in Table 1.

Table 1. Logarithm of the stability constants of binary and ternary complexes of $\mathrm{M}^{2+}$ at $25^{\circ} \mathrm{C}, 0.1 \mathrm{M}, \mathrm{NaNO}_{3}{ }^{*}$

\begin{tabular}{ccccc}
\hline \multicolumn{5}{c}{$p K_{H_{2}(T r p)}^{H}=2.22 \pm 0.08$} \\
\hline \multicolumn{5}{c}{$p K_{H(T r p)}^{H}=9.14 \pm 0.03$} \\
\hline No. & Species & $\operatorname{logK}^{\mathbf{a}}$ & $\Delta \log \mathbf{K}^{\mathbf{b}}$ & Ref. \\
\hline 1 & $\mathrm{Cu}^{2+}$ & $8.05 \pm 0.05$ & - & {$[13]$} \\
2 & $\mathrm{Cu}(\mathrm{Bpy})^{2+}$ & $9.02 \pm 0.06$ & $0.97 \pm 0.08$ & - \\
3 & $\mathrm{Cu}(\text { Phen })^{2+}$ & $9.36 \pm 0.08$ & $1.31 \pm 0.09$ & - \\
\hline
\end{tabular}

* The given errors are three times the standard error of the mean value or the sum of the propabable systematic errors. a according eq. (4). ${ }^{b}$ according eq. (8).

The order of the resulted stability constants are $\mathrm{Cu}^{2+}<$ $\mathrm{Cu}(\mathrm{Bpy})^{2+}<\mathrm{Cu}(\mathrm{Phen})^{2+}$. Figure 2 shows Schematic struc- 
tures of the species with interactions according to equilibrium (4) \& (7) for $\mathrm{Cu}$ (Phen)(Trp). The results of the acidity constants show good agreement with reported values[13]. The reported stability constant of $\mathrm{Cu}$ (Trp) complex is similar to our results (tab. 1).The difference between stability constants according eq. (8) show that mixed ligand complexes[14-17] formed by a divalent $3 \mathrm{~d}$ ion, a heteroaromatic $\mathrm{N}$ base and an $\mathrm{O}$ donor ligand possess increased stability. Now one can calculate the free energy $\Delta \mathrm{G}$, used $\Delta \log \mathrm{K}$ received from eq. 8 (tab. 1). We receive for $\Delta \log K_{C u(B p y)(T r p)}^{C u(B p y)}$ $5.441 \mathrm{~kJ} / \mathrm{mol}$ and for $\Delta \log K_{C u(P h e n)(T r p)}^{C u(P h e)} 7.349 \mathrm{~kJ} / \mathrm{mol}$, which are considerable high. This means that interaction between $\mathrm{Cu}(\mathrm{Har})^{2+}$ and $\operatorname{trp}^{2-}$ is relative strong and the observed increased stability indicate strong complex bilding of ternary systems.

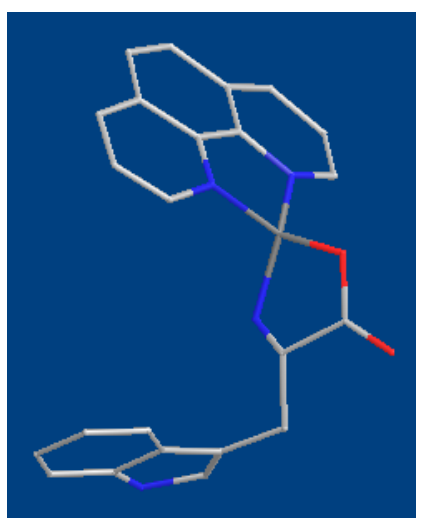

Figure 2. Schematic structures of the species with interactions according to equilibrium (4) \& (7) for $\mathrm{Cu}(\mathrm{Phen})(\mathrm{Trp})$. The structure in the right part of the figure was drawn with the program CS Chem 3D, version 3.5, from Cambridge Software Corporation

\section{REFERENCES}

[1] IUPAC-IUBMB Joint Commission on Biochemical Nomenclature. Recommendations on Organic \& Biochemical Nomenclature, Symbols \& Terminology etc.

http://www.chem.qmul.ac.uk/iupac/AminoAcid/. Retrieved 2007-05-17. Gollnick P, Babitzke P, Antson A, Yanofsky C, 2005, "Complexity in regulation of tryptophan biosynthesis in Bacillus subtilis". Annu. Rev. Genet. 39: 47-68
[2] Moffat, A.C., Jackson, J.V., Moss, M.S., Widdop, B., 1986: Clarke's Isolation and Identification of Drugs, The Pharmaceutical Press, London, UK p. 1056

[3] Fiorucci, A.R., Cavalheiro, E.T.G., 2002, The use of carbon paste electrode in the direct voltammetric determination of tryptophan in pharmaceutical formulations, J. Pharm. Biomed. Anal. 28, 909-915

[4] H.H. Hussey, Sleep inducement by L-tryptophan, J. Am. Chem. Soc. 87, 1126, (1974)

[5] Cioni, P., Strambini, G.B., 2002, Tryptophan phosphorescence and pressure effects on protein structure, Biochim. Biophys. Acta, 1595, 116-130

[6] Liang, Y.D., Song, J.F., 2005, Flow-injection chemiluminescence determination of tryptophan through its peroxidation and epoxidation by peroxynitrous acid, J. Pharm. Biomed. Anal.38, 100-106

[7] Altria, K.D., Harkin, P., Hindson, M.G., 1996, Quantitative determination of tryptophan enantiomers by capillary electrophoresis, J. Chromatogr. Biomed. 686, 103-110

[8] Handbook of Chem. \& Physics, 1975, 55 , p.129

[9] Miranda J.L, Felcman J, 2003, Polyhedron, 22 ; p. 225-233

[10] Sigel H, 1973, Metal Ions in Biological Systems, Mixed Ligand Complexes, Marcel Dekker, New York, vol.2; p. 3

[11] Felcman J, Miranda J.L, 1997, J. Braz. Chem. Soc., 8 ; p. 575

[12] Pettit L.D, Powel A., 1998, IUPAC Stability Conatants Database, Release 3, version 3.02, Academic Software Timble, UK. Sigel H., Zuberbuehler A.D., Yamauchi O. 1991, Anal. Chim. Acta, 63, p. 255

[13] Sigel H., Naumann C.F., 1976, J. Am. Chem. Soc., 98(3), 730-739

[14] Sajadi, S.A. A., Song, B., Sigel, H., 1998, Inorg. Chim. Acta, 283, 193-201

[15] Sajadi, S. A. A., Song, B., Gregan, F., Sigel, H., 1999, Inorg. Chem., 38(3), 439-448

[16] Sajadi, S. A. A., Song, B, Gregan, F., Sigel, H., 1997, Bull. Chem. Soc. Ethiop., 11(2), 121-130

[17] Sajadi, S. A. A., Bastian, M., Sigel, H., 1995, J. Inorg. Biochem., 59(2,3), 139

\footnotetext{
iTrp: L-Tryptophan

ii Bpy: 2,2'-Bipyridyl

iii Phen: 1,10-phenanthroline

${ }^{\text {iv }}$ Har: Heteroaromatic ligand such as Bpy or Phen
} 